\title{
Postintubation Tracheoesophageal Fistula - Diagnosis, Treatment and Prognosis
}

\author{
Ciprian Bolca', Valerian Păvăloiu' ${ }^{1}$, Georgiana Fotache', Mihai Dumitrescu', Andrei Bobocea', Mihai Alexe ${ }^{2}$, \\ Genoveva Cadar ${ }^{3}$, Radu Stoica ${ }^{3}$, Cristian Paleru', Ioan Cordoș ${ }^{1}$
}

'Thoracic Surgery Division, "Marius Nasta" Institute of Pneumology, Bucharest, Romania

${ }^{2}$ Bronchology Division, "Marius Nasta" Institute of Pneumology, Bucharest, Romania

${ }^{3}$ ICU Division, "Marius Nasta" Institute of Pneumology, Bucharest, Romania

Corresponding author:

Bolca Ciprian, MD

"Marius Nasta" Institute of Pneumology

Thoracic Surgery Division

90 Viilor street, sect 5, Bucharest, R0

E-mail: bolcaciprian@gmail.com

\section{Rezumat}

Fistula esotraheală postintubație - diagnostic, tratament și prognostic

Introducere: Fistula esotraheală postintubație este o complicație severă, apărută în anumite condiții la pacienții care necesită ventilație mecanică pentru o perioadă îndelungată de timp.

Material şi metodă: Articolul prezintă o serie de 11 pacienți cu fistula esotraheală postintubație operați în clinica noastră în perioada 2005 - 2015. Abordul anterior cu rezecție de trahee a fost preferat la 10 dintre aceşti pacienți, într-un caz cu o fistulă de dimensiuni mari preferând să efectuăm o intervenție chirurgicală atipică. Trei dintre pacienții seriei au fost operați înainte de sevrarea de ventilator în încercarea de a ajuta la desprinderea de ventilația mecanică. Două cazuri au fost operate în urma recidivei fistulei după tentative de închidere în alte servicii chirurgicale.

Rezultate: Doi pacienți (ambii din grupul celor care nu au fost sevrați de ventilator) au decedat în urma unor complicații specifice intubației continuate după rezecția traheală (dehiscență anastomotică cu mediastinită şi fistulă traheo-vasculară în trunchiul arterial brahiocefalic). Restul de 9 pacienți ai seriei au avut 0 evoluție bună, cu restaurarea căii aeriene şi deglutiție normală.

Concluzii: Abordarea chirurgicală a acestei patologii are succes în servicii specializate în chirurgie traheală şi esofagiană. Alegerea momentului operator este de mare importanță pentru obținerea unor rezultate bune.

Cuvinte cheie: fistula esotraheală, stenoză trahee, rezecție traheală 


\section{Abstract}

Introduction: Postintubation tracheoesophageal fistula is a severe complication occurring under certain conditions in patients that require prolonged mechanical ventilation.

Material and methods: This article focuses on a sample of 11 patients with postintubation tracheoesophageal fistula, operated in our department between 2005 and 2015. The anterior approach with tracheal resection was performed in 10 of these patients, while an atypical surgical technique was preferred in a case involving a large-sized fistula. Three of these patients were subject to surgery while still on the ventilator, in order to help weaning them from mechanical ventilation. Two patients were operated following a relapse of the fistula, after attempts of closing it in other surgical units.

Results: Two patients (of those who were still on mechanical ventilation) died from intubation-related complications that persisted after tracheal resection (anastomotic dehiscence with mediastinitis and tracheoarterial fistula in the brachiocephalic arterial trunk). The nine remaining patients improved, with their airways restored and having regained normal deglutition.

Conclusions: The surgical approach of this pathology is successful in surgical units that are specialised in tracheal and oesophageal surgery. Adequately timing the surgery is crucial for a good outcome.

Key words: tracheoesophageal fistula, tracheal stenosis, tracheal resection

\section{Introduction}

Postintubation tracheoesophageal fistula (TEF) is a severe complication found in patients that require prolonged mechanical ventilation. It is induced by ischemia of the posterior tracheal wall caused by the overinflated cuff of the endotracheal or tracheotomy tube that is almost always in contact with a nasogastric tube used for either feeding or aspirating the gastric content (Fig. 1). An endotracheal tube cuff where the pressure is constantly over $25-30 \mathrm{mmHg}$ may cause injury to the tracheal mucosa even after 2 hours! $(1,2)$. The widespread use of High volume - Lo pressure endotracheal tubes over the past 35 years has significantly reduced the incidence of this complication, which still occurs in some $0.5 \%$ of the patients who require prolonged mechanical ventilation (3,4 (Fig. 2). With this

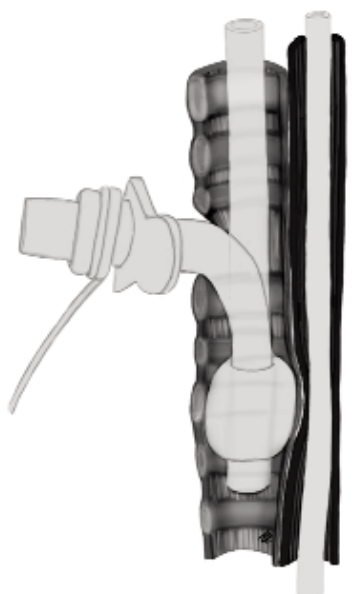

Figure 1. Overinflated tracheostomy/intubation tube cuff in transparietal contact with the nasalgastric tube

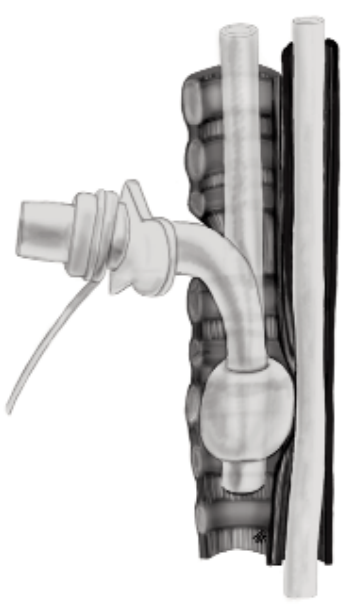

Figure 2. Tracheoesophageal fistula formed at the contact point between the probes 
type of tubes, an approximately $15 \mathrm{mmHg}$ pressure is enough to guarantee sealing of the ventilation tube (5). Other risk factors leading to TEF are: excessive movement of the tracheostomy tube (in case of smaller-thanneeded diameter), restlessness, malnutrition, hypotension, sepsis, steroid treatment and diabetes (6).

Surgical treatment is standard, as the operation is the only solution for these patients; usually, such fistulas are large in size, sometimes detected late, with a fistulous opening that is well epithelialized, which makes it virtually impossible to close spontaneously or through conventional methods (7). Optimal timing of the surgery is vital in the management of this pathology. Some authors recommend surgery while the patient is still intubated, to help with ventilator weaning (8), while others propose to start by stabilizing the patient, with mechanical ventilation weaning as a prerequisite for initiating the surgical treatment of the fistula (9).

In most cases, tracheal stenosis induced by the cuff of the endotracheal tube is associated to this complex pathology, which means that segmental tracheal resection is also part of the surgery (6).

\section{Material and Methods}

Between 2005 and 2015, 11 patients with tracheoesophageal fistula were subject to surgical treatment. The sample comprised 7 men and 4 women, aged 19 to 61 years. Nine patients were referred to our clinic from intensive care units after prolonged mechanical ventilation that lasted for periods ranging between 24 and 53 days. Three of them were still under mechanical ventilation when they were transferred for closure of the fistula to increase their chances of ventilator weaning. In nine patients, the prolonged intubation was caused by various politrauma, while diabetes coma and prolonged status epilepticus were the causes in the other two cases. Seven patients had mechanical ventilation through the tracheostomy tube. The fistula was located in the upper third of the trachea in nine cases and in the median third in the other two. All patients had tracheal stenosis to a certain degree, which required tracheal resection during the surgery in ten of the cases, except for a female patient with a large fistulous opening where we performed an atypical surgical procedure, as described below. In all our cases, the patients also had a nasogastric tube. Two of them were subject to surgery for closing the fistula after being referred to us for relapse.

All patients were diagnosed while still under mechanical ventilation. A sudden increase in secretion volume on the endotracheal tube and ventilation issues are the first discrete signs in such cases. Esophagoscopy and/or bronchoscopy were used for diagnosis certainty (Fig. 3). Conventional treatment measures were first taken for ventilator weaning purposes; the endotracheal tube or the tracheostomy tube was placed below the fistula, the nasogastric tube was removed, the gastrostomies (if present) were used solely for aspiration of the gastric content and feeding was strictly parenteral or by jejunostomy, as the sepsis caused by lung contamination was treated aggressively with broad-spectrum antibiotics. In patients where extubation was successful,

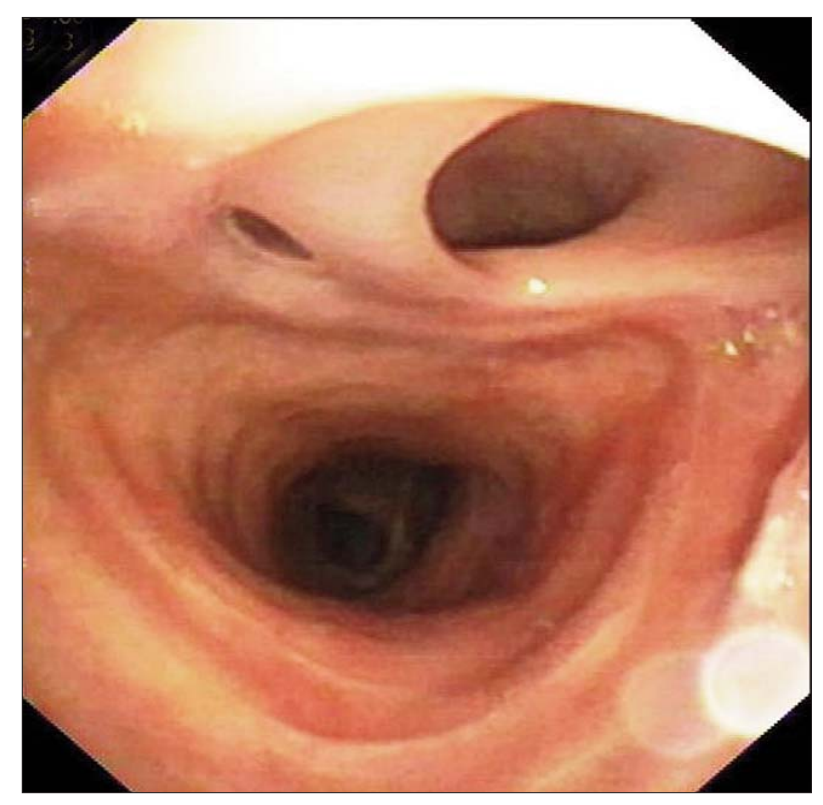

Figure 3. Large dimensions of a tracheoesophageal fistula bronchoscopic aspect 
any per os administration was discontinued and they were referred to our clinic as soon as possible.

The anaesthetic and surgical techniques specific to tracheal surgery, coupled with optimum coordination with the anaesthetist throughout the surgery are crucial for a favourable intra-and post-operative outcome $(10,11)$. The operations were performed under general anaesthesia, with orotracheal intubation or ventilation through the tracheostomy tube, with the tube placed below the fistulous opening. During the entire anaesthetic process, starting with the induction, avoiding the contamination of the tracheobronchial trunk or even its flooding with gastric content is important. Prior to surgery, an antacid is administered and, if possible, the stomach content is pumped to the largest extent possible. Regardless of the patient's state, whether or not it is an emergency, and of the chosen surgical technique, the positioning of the intubation or tracheostomy tube should be checked by fibrobronchoscopy to make sure the tip of the tube is beyond the fistula and its cuff isolates the airway (12).

After incision of the trachea, if performed, the patients were ventilated through an endotracheal tube passed through the operating wound and placed in the distal trachea. In tracheal surgery, extubating the patient immediately after completing the surgery is very important, as failure to do so may lead to severe complications.

We prefer the anterior transtracheal approach of the fistulous opening, which was actually used in 10 of our cases. Kocher cervicotomy is usually sufficient, as most fistulas are located in the upper third of the trachea; partial sternotomy may be needed when the fistula is in the median third of the trachea, which was the case in one of the patients treated in this group. Airway incision is the next step in this type of surgery, followed by resection of the tracheal stenosis all the way to the healthy tissue in order to avoid re-stenosis of the airway after anastomosis. The part of the resected trachea was 2 to $4.5 \mathrm{~cm}$ long (49 cartilage rings), depending on how much of the trachea was damaged by both stenosis and the tracheostomy tube opening. Trachea dissection, given its metameric vascularization, should be performed strictly on the part to be resected so as to avoid damaging the sources of blood supply to the anastomosis ends. Once the tracheal piece was removed, the patient was ventilated through the distal end of the airway, by passing an endotracheal tube through the operating wound. The access to the fistulous opening (usually large) on the anterior wall of the oesophagus is also very good under such circumstances (Fig. 4). We didn't have patients with small fistulas (the smallest was $1^{-} \mathrm{cm}$ wide) in our sample so that we could perform direct closure, as we will show below.

The opening in the anterior oesophageal wall is carefully dissected to identify and separate the muscle layer from the oesophageal mucosa. The layers are sutured separately, lengthwise, and we prefer to use 4.0 Polydioxanone absorbable monofilament thread into a continuous, simple suture. Finding defects so large that the oesophagus suture causes stenosis of the digestive lumen is highly unlikely. Once the oesophageal suture is done, the termino-terminal tracheal anastomosis is performed with the same type

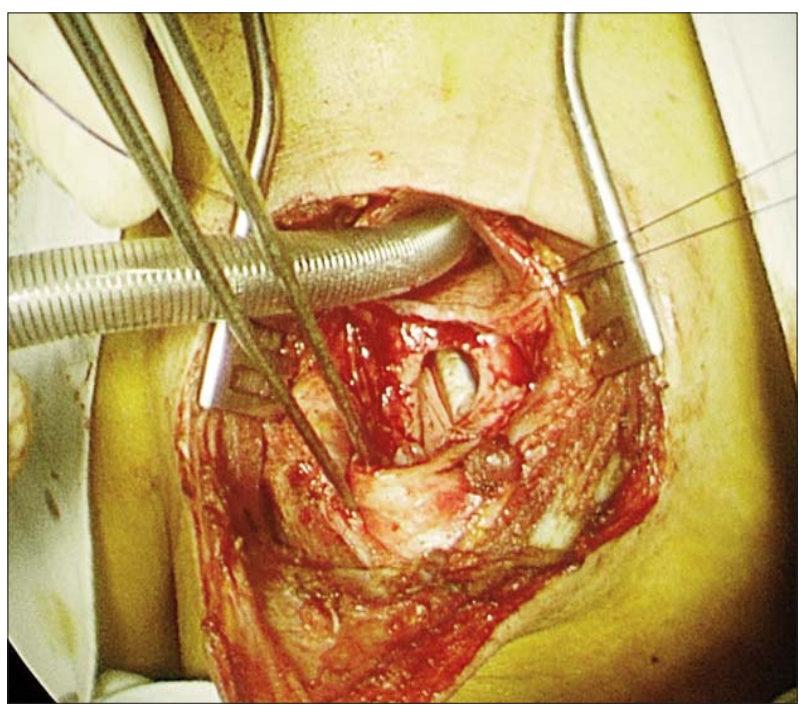

Figure 4. Intraoperative aspect after segmental tracheal resection; crossfield intubation into the distal trachea; fistula to the anterior oesophageal wall with a clear view of the nasalgastric tube 
of thread. The anastomosis can be done in either continuous or separate suture, but we prefer the former. Usually, if the initial stenosis is high and the anastomosis is performed between the trachea and the cricoid cartilage, we perform a continuous suture on the posterior wall and, in case of diameter mismatch, the anterior wall is closed with separate sutures. In two of the cases, because the tracheal stenosis was long and tension in the anastomosis line was likely to occur (with typical subsequent complications), it was decided, after the suture of the posterior wall, to position a T-tube (Montgomery type) in the tracheal lumen; the tube was then removed 6 months after surgery and the remaining openings were closed under local anaesthesia, with good results.

It is extremely important that a nearby muscle or tissue be inserted between the oesophageal suture line and the trachea, depending on the approach applied, so as to protect the suture and prevent a relapse of the fistula (Fig. 6, 7, 8, 9), although some authors claim this manoeuvre is not an absolute must (13). If tracheal resection is also performed, the oesophageal and tracheal suture lines will not be on the same level, but if tracheal resection is not performed, the two sutures will come in contact, which makes the insertion of a flap between the two organs even more important. If the brachiocephalic arterial trunk is near the tracheal anastomosis, it should also be protected by a nearby flap to avoid a disastrous complication, such as its fistulisation in the airway.

The technical aspects described so far were used in 10 cases in our sample. As mentioned before, we also had a case where we performed atypical surgery; a 40-year old female patient, intubated for 24 days following head injury, transferred to our department with a $7 \mathrm{~cm}$ long fistula between the oesophagus and the trachea, a relapse after an unsuccessful attempt of directly closing both organs through a transcervical approach in a different surgical unit. Actually, only the first three subcricoid cartilage rings and the last three above the carina of the trachea were intact. Initially, her extremely poor health status, with sepsis and

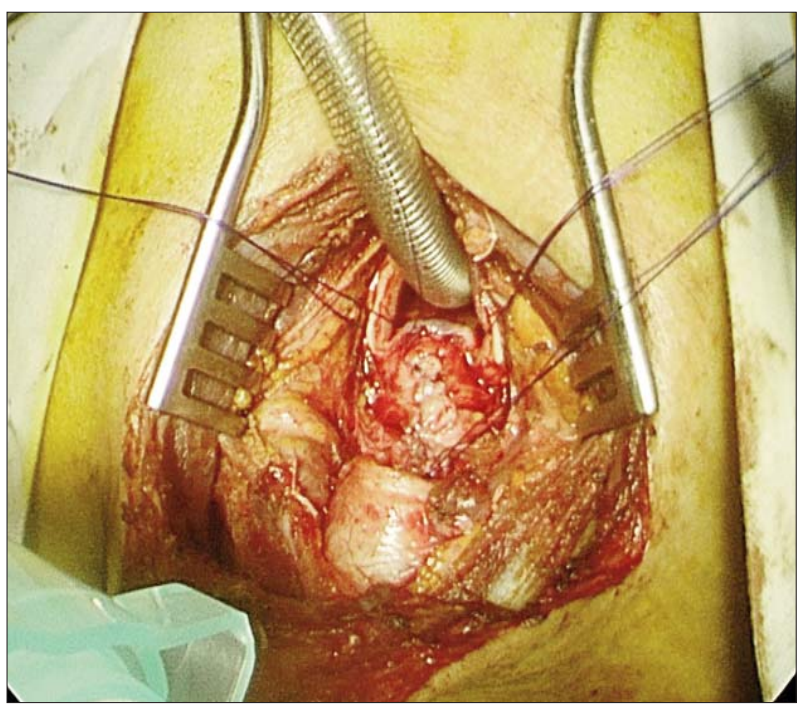

Figure 5. Longitudinal suture of the oesophagus

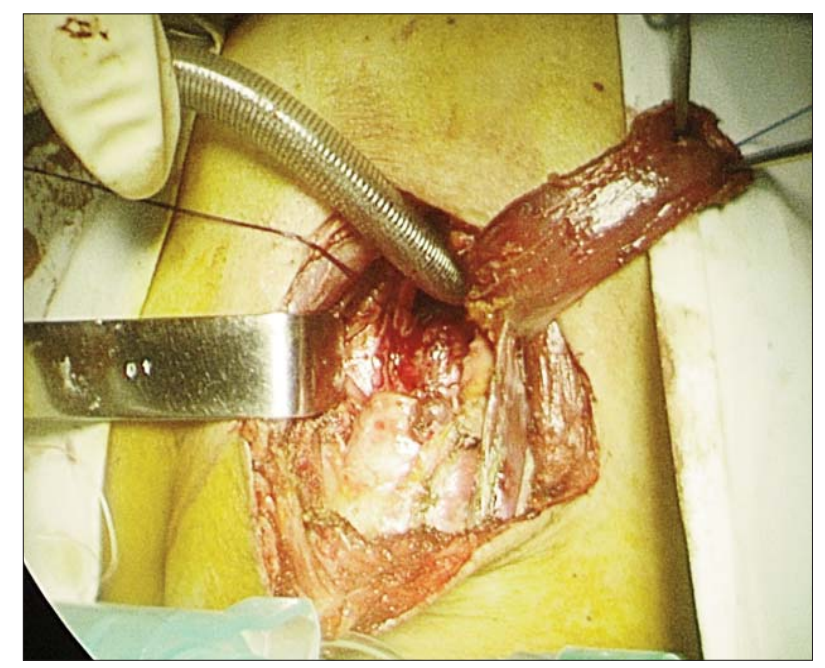

Figure 6. Local muscle flap prepared for interposition between the suture lines

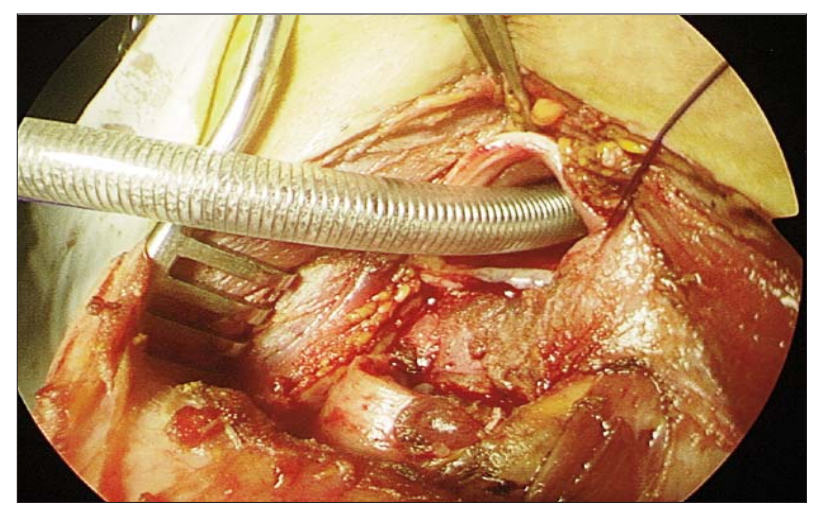

Figure 7. Muscle flap positined over the oesophageal 


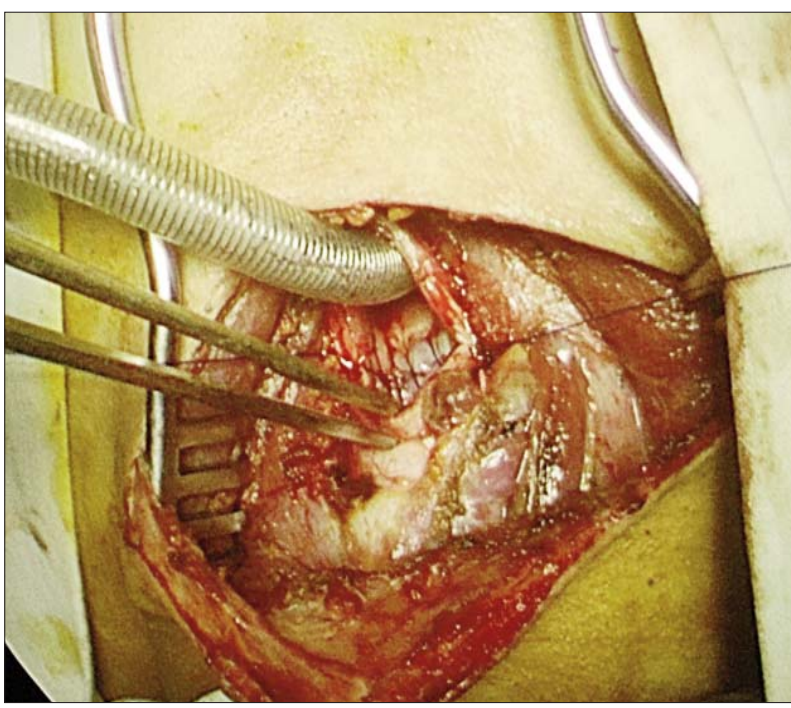

Figure 8. Tracheal anastomosis - posterior wall

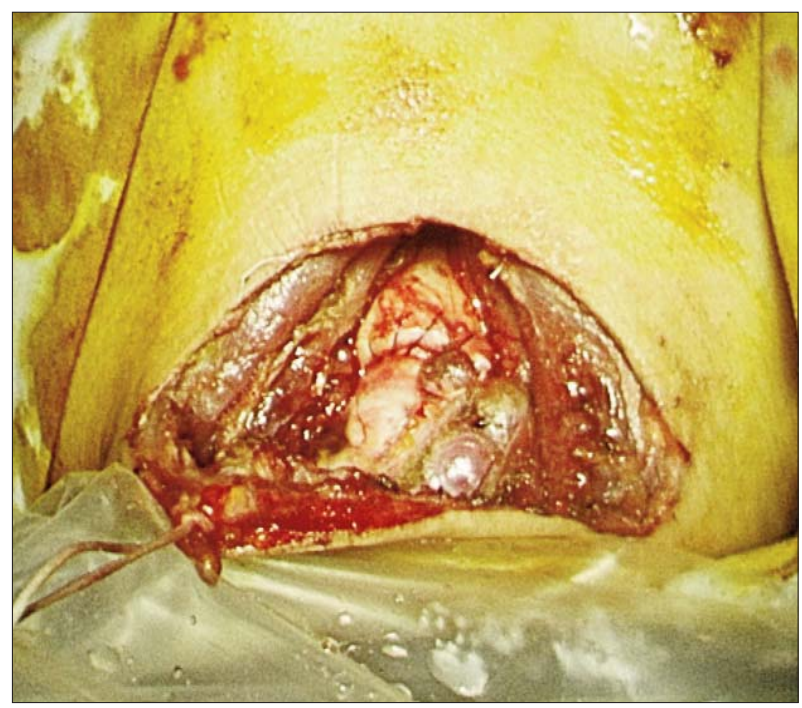

Figure 9. Tracheal anastomosis - final aspect malnutrition, hypoproteinemy and bilateral basal aspiration pneumonia, called for intensive treatment to restore proper nutrition and the electrolyte balance, plus recovery from severe sepsis. First, we performed a feeding jejunostomy and a gastrostomy for suction of the gastro-biliary fluid. Three weeks after feeding by jejunostomy, suction of the stomach content and biliary fluid, repeated bronchoaspiration for lung cleansing and administration of broad-spectrum antibiotics to fight multidrug resistant bacterias, we performed an oesophageal bypass by means of a retrosternal gastric tube. Unlike the standard bypass surgery, we dissected the oesophagus through a transabdominal and transcervical approach to reach the upper and lower ends of the fistula that we stapled and cut. The patient was virtually left with an oesophageal segment attached to the trachea, like some large-sized tracheal diverticulum, thus preventing lung contamination.

In our second patient referred to us for a relapse, the initial surgery consisted of closing the oesophagus with a flap of bovine pericardium and performing a direct suture of the posterior tracheal wall, then placing a tracheostomy tube through the tracheal stenosis. 10 days after the surgery, due to necrosis of the oesophageal wall, the fistula regained its permeability, so the patient was referred to us. The previouslydescribed standard procedure was performed, with the anterior approach, the resection of the tracheal segment with stenosis, the removal of the infected bovine pericardium flap, then repair of the oesophageal opening with a flap from the tracheal membranous wall, covering the suture with a muscle flap from the cervical region and performing the tracheal anastomosis using a Montgomery tube for the anterior wall due to the excessive length $(4.5 \mathrm{~cm})$ of the tracheal segment that had to be removed.

\section{Results}

Two of the patients died after surgery, one on the $4^{\text {th }}$ day, due to an arterial-tracheal fistula (between the brachiocephalic arterial trunk and the trachea), and the other on the $21^{\text {st }}$ day after surgery, due to severe sepsis caused by a mediastinitis induced by tracheal anastomotic dehiscence. We should add that both cases were part of the three-patient subgroup subject to surgery while still on the ventilator, who did not fully recover from their underlying disease, thus requiring further mechanical ventilation after the surgery. The third patient was placed under ventilation for another three days, then, 
in the absence of lung contamination and with the aggressive specific treatment discontinued, he was extubated and subsequently released from hospital in better state of health.

The female patient subject to the oesophageal bypass had a slow, favourable recovery, with the per os feeding gradually resumed and significant improvement in her nutrition; once the lung contamination with gastric-biliary fluids ceased, the aspiration pneumonia remitted, so the patient was discharged from hospital on the $21^{\text {st }}$ day after surgery in much better health. She was referred to a neuromotor recovery clinic for treatment of post-traumatic sequelae. As we mentioned previously, two patients were discharged with a tracheal Montgomery tube that was removed 6 months after surgery; another patient had temporary paralysis of the recurrent laryngeal nerve that was subsequently resolved.

The patients were subject to endoscopic checks (bronchoscopy and/or oesophagoscopy) one month, 6 months and one year after surgery, but no signs of fistula relapse or stenosis of the airway or digestive lumen were revealed.

\section{Discussion and Conclusions}

The samples of such cases described in the literature include a limited number of patients and usually cover long periods of time $(6,8,9$, 14,15); actually, our sample comprises a number of 11 cases over a 10-year period, although our department is prominent in tracheal surgery. On the one hand, this complication is rare, but on the other hand, not all patients that have it qualify for major surgery, especially due to the underlying condition that required prolonged mechanical ventilation in the first place. The largest sample in the literature assembles 54 cases of postintubation tracheoesophageal fistula over a period of 35 years (9); the article concerned (as well as other publications on the same topic) also includes benign esotracheal fistulas of a different etiology - postoperative, posttraumatic, infectious - but subject to similar treatment. The full sample described in the said article features another 20 cases of benign esotracheal fistula with causes other than prolonged intubation, which only goes to show that trauma caused by the cuff of the endotracheal tube is the most common cause of such fistulas. In our practice, we have not seen this condition occurring in a different etiological context.

In rare cases, such fistulas may occur in the lower third of the trachea, so the approach changes substantially, as the most appropriate way to tackle the distal trachea is right thoracotomy. The anterior transsternal transpericardial approach may also be used, but the trachea is much more difficult to reach, as it is located behind the large vessels and the pericardium. In these cases, during the surgery, the patient can be ventilated by intubating the left lung directly through the surgical wound or, if available, by using the high frequency jet ventilation (HFJV) devices, which are more convenient and clean (10). When the fistula is positioned right above the carina of the trachea, avoiding lung contamination is practically impossible as no cuffed endotracheal tube can be placed below the fistulous opening. The options in this case are either oesophageal diversion, or emergency surgery with tracheal resection. Emergency resection of the air duct (if stenosis is present) can also be considered when the fistula is diagnosed in the first 24 to 48 hours from extubation, in patients with a satisfactory health status and lung contamination at minimum levels $(6,16,17)$.

In case the fistula is small-sized and diagnosed early, the simple suture of both the oesophageal and the tracheal defect may be performed, especially since such cases are usually not associated with tracheal stenosis. In this case, the fistula can be approached from the side, but layering a tissue flap between the two suture points is still recommended, especially since the sutures are now at the same level. An anterior transtracheal approach is much more convenient to perform (in particular for surgeons with tracheal surgery experience), as it enables a clear assessment of injuries to the trachea which, if not affected by stenosis, may present ischemic, inflammatory, malacic injuries that, unless 
resected, might result in various problems, including delayed stenosis, requiring subsequent surgery (6).

As for timing the surgery, it's better to have the patient off the ventilator before going through with the operation. The need of postoperative intubation due to the initial pathology poses major issues related to the subsequent outcome for the patient, given that the cause of the fistula was not removed. Among this group of patients, a careful selection should be made of those where the fistula is the main reason preventing extubation; any patient with systemic deficiencies requiring post-surgery mechanical ventilation is highly likely to have a negative outcome. In our sample, after a first successful operation on such a patient, the following two patients died from complications typical to prolonged intubation after tracheal resection, namely anastomosis dehiscence and arterial-tracheal fistula (18).

Oesophageal stenting in the attempt to close or seal such fistulas has, unfortunately, poor results according to data in the literature (19). Sealing the fistula was successful in a small number of patients (20), but there are no reports of closing a fistula through conventional methods. On the other hand, placing oesophageal stents may result in the enlargement of these fistulas (21). Tracheal stenting should be avoided, as it causes a strong inflammatory reaction and significant granulation in the tracheal mucosa, which is already sensitized by the presence of the cuff of the endotracheal tube.

Practically, once the fistula is diagnosed, start with conventional measures to stop lung contamination:

- re-assess the intubation of the patient and place the cuffed endotracheal tube below the fistula, inflating it with the minimum pressure needed for efficient ventilation;

- remove the nasogastric tube;

- perform an aspiration gastrostomy and a feeding jejunostomy;

- suction of secretions from the oral cavity may prove useful;
- aggressive treatment of the aspiration pneumonia with broad-spectrum antibiotics is strongly recommended, coupled with repeated bronchoaspirations and kinetotherapy.

If such manoeuvres won't prevent lung contamination or if the fistulas are large and lodged in the lower third of the trachea where they cannot be controlled through such methods, then oesophageal diversion with cervicostomy and closure of the oesophagus in the cardia region becomes the only option, followed by oesophagoplasty at a later time. After successful weaning from the ventilator, closing the fistula and restoring a patent airway, without the need for post-surgery mechanical ventilation, gives the best possible chances to these patients.

This pathology is uncommon and requires complex management, tailored to each particular case, depending on pre-existing conditions, as well as anatomical and morphological characteristics of the patient. In order to get a satisfactory outcome, these patients should be treated in surgical and intensive care units that specialize in tracheal and oesophageal surgery.

\section{References}

1. Klainer AS, Turndorf $H$, Maewal $H$, Allender P. Surface alterations due to endotracheal intubation. Am J Med. 1975;58(5):674-83.

2. Stauffer JL, Olson DE, Petty TL. Complications and consequences of endotracheal intubation and tracheotomy. A prospective study of 150 critically ill adult patients. Am J Med. 1981;70(1):65-76.

3. Harley HR. Ulcerative tracheo-oesophageal fistula during treatment by tracheostomy and intermittent positive pressure ventilation. Thorax. 1972;27(3):338-52.

4. Mathisen DJ, Grillo HC, Wain JC, Hilgenberg AD. Management of acquired nonmalignant tracheoesophageal fistula. Ann Thorac Surg. 1991;52(4):759-65.

5. Dullenkopf A, Gerber A, Weiss M. Fluid leakage past tracheal tube cuffs: evaluation of the new Microcuff endotracheal tube. Intensive Care Med. 2003;29(10):1849-53. Epub 2003 Aug 16.

6. Macchiarini P, Verhoye JP, Chapelier A, Fadel E, Dartevelle P. Evaluation and outcome of different surgical techniques for postintubation tracheoesophageal fistulas. J Thorac Cardiovasc Surg. 2000;119(2):268-76.

7. Dartevelle P, Macchiarini P. Management of acquired tracheoesophageal fistula. Chest Surg Clin N Am. 1996;6(4):819-36.

8. Shen KR, Allen MS, Cassivi SD, Nichols FC 3rd, Wigle DA, Harmsen WS, et al. Surgical management of acquired nonmalignant tracheoesophageal and bronchoesophageal fistulae. Ann Thorac Surg. 2010;90(3):914-8; discussion 919. doi: 10.1016/j.athoracsur.2010.05.061. 
9. Muniappan A, Wain JC, Wright CD, Donahue DM, Gaissert H, Lanuti $M$, et al. Surgical treatment of nonmalignant tracheoesophageal fistula: a thirty-five year experience. Ann Thorac Surg 2013:95(4):1141-6. doi: 10.1016/.jathoracsur.2012.07.041. Epub 2012 Sep 20.

10. Stoica R, Cordos I. Surgical and anesthetic coordination during tracheal and carinal resections and reconstruction. Chirurgia (Bucur). 2007:102(6):681-6. Romanian

11. Cordos I. Surgical treatment of tracheal and main bronchi stenosis-segmental resection. Chirurgia (Bucur). 2006 ;101(4):411-4. Romanian

12. Horishita $T$, Junichi 0 , Kouichiro M. Unique anesthetic management of a patient with a large tracheoesophageal fistula using fibreoptic bronchoscopy. Anesth Analg. 2003;97(6):1856.

13. Camargo JJ, Machuca TN, Camargo SM, Lobato VF, Medina CR. Surgical treatment of benign tracheo-oesophageal fistulas with tracheal resection and oesophageal primary closure: is the muscle flap really necessary? Eur J Cardiothorac Surg. 2010;37(3):576-80. doi: 10.1016/j.ejcts.2009.08.023. Epub 2009 0ct 2.

14. Baisi A, Bonavina L, Narne S, Peracchia A. Benign tracheoesophageal fistula: results of surgical therapy. Dis Esophagus. 1999;12(3):209-11.

15. Krajc T, Janík M, Lucenic M, Benej R, Harustiak S. Possibilities and results of surgical treatment of benign tracheoesophageal fistula.
Rozhl Chir. 2010;89(8):478-89. Slovak

16. Cordos I, Bolca C, Paleru C, Posea R, Stoica R. Sixty tracheal resections - single center experience. Interact Cardiovasc Thorac Surg. 2009:8(1):62-5; discussion 65. doi: 10.1510/ icvts.2008. 184747. Epub 2008 Oct 8.

17. Krajc T, Janik M, Benej R, Lucenic M, Majer I, Demian J, et at. Urgent segmental resection as the primary strategy in management of benign tracheal stenosis. A single center experience in 164 consecutive cases. Interact Cardiovasc Thorac Surg. 2009; 9(6): 983-9. doi: 10.1510/icvts.2009.213215. Epub 2009 Sep 15

18. Bolca C, Saon C, Paleru C, Matache R, Codreși M, Dănăilă 0, et al Tracheal stenosis--diagnostic and therapeutic principles, results. Pneumologia. 2010;59(3):132-8. Romanian

19. Eleftheriadis E, Kotzampassi K. Temporary stenting of acquired benign tracheoesophageal fistulas in critically ill ventilated patients. Surg Endosc. 2005;19(6):811-5. Epub 2005 May 3.

20. Blackmon SH, Santora R, Schwarz P, Barroso A, Dunkin BJ. Utility of removable esophageal covered self-expanding metal stents for leak and fistula management. Ann Thorac Surg. 2010;89(3):931-6; discussion 936-7. doi: 10.1016/j.athoracsur.2009.10.061.

21. Han Y, Liu K, Li X, Wang X, Zhou Y, Gu Z, et al. Repair of massive stent-induced tracheoesophageal fistula. J Thorac Cardiovasc Surg. 2009;137(4):813-7. doi: 10.1016/j.jtcvs.2008.07.050. Epub 2009 Jan 18 